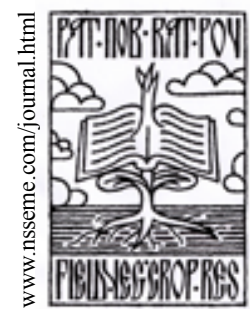

\title{
Solubilization of Inorganic Phosphate by Endophytic Pseudomonas sp. from French Bean Nodules
}

\author{
Zoran Dinić • Milan Ugrinović • Predrag Bosnić • Mira Mijatović • \\ Jasmina Zdravković • Miroslav Miladinović • Dragana Jošić
}

\author{
received: 4 June 2014, accepted: 19 September 2014 \\ published online: 24 September 2014 \\ (c) 2014 IFVC \\ doi:10.5937/ratpov51-6222
}

\begin{abstract}
Summary: Phosphorus (P) is one of the major essential macronutrient for plant growth. Phosphate solubilizing bacteria (PCB) is a group of heterotrophic bacteria capable of solubilizing organic and inorganic phosphorus from insoluble compounds, releasing phosphate available for plant uptake. In this study endophytic bacteria were isolated form nodules of French bean grown in different intercropping systems. Only 14 out of 158 endophytic isolates were able to solubilize tricalcium phosphate (TCP). None of them were observed to solubilize $\mathrm{FePO}_{4}$ and $\mathrm{AlPO}_{4}$. Eight isolates formed solubilization zones larger than $3 \mathrm{~mm}$ and were used for further test. The TCP solubilization was measured in liquid Pikovskaya medium and ranged from 14-182 $\mu \mathrm{gm} l^{-1}$ of soluble phosphorus. TCP solubilization was correlated with acidity and $\mathrm{pH}$ decreasing from 7.4 to 5.57 and 4.91 for the lowest and the highest solubilizer, respectively, were observed. The most efficient isolate MP18 was selected and identified as Pseudomonas sp. according to $16 \mathrm{~S}$ rRNA gene analysis.
\end{abstract}

Keywords: endophytic bacteria, French bean nodules, phosphate solubilizing bacteria, Pseudomonas, soil pH

\section{Introduction}

Phosphorus (P) is an essential mineral nutrient most commonly limiting the growth of crops. The phosphate fertilization of soils has always been important because vast areas of agricultural land can be poor if the soil has a phosphate deficiency. Phosphorus is typically insoluble or poorly soluble in soils (Banerjee et al. 2010). Soil P dynamics is characterized by physicochemical (sorptiondesorption) and biological (immobilizationmineralization) processes (Khan et al. 2009). Anthropogenic addition to the soil can easily be precipitated into insoluble forms such as TCPtricalcium phosphate $\left[\mathrm{Ca}_{3}\left(\mathrm{PO}_{4}\right)_{2}\right], \mathrm{FePO}_{4}$ and

Z. Dinić • M. Miladinović • D. Jošić ${ }^{*}$

Institute of Soil Science, Teodora Drajzera 7, 11000 Belgrade, Serbia

M. Ugrinović • M. Mijatović • J. Zdravković

Institute for Vegetable Crops, Karađorđeva 71, 11420 Smederevska Palanka, Serbia

\section{P. Bosnić}

University of Belgrade, Institute for Multidisciplinary Research, Kneza Višeslava 1, 11000 Belgrade, Serbia
$\mathrm{AlPO}_{4}$ (Banerjee et al. 2010). Anthropogenic addition of $\mathrm{P}$ fertilizers can often have negative effects on ecosystems such as toxic effect on plants and freshwater eutrophication (Madigan $\&$ Martinko 2006). For these reasons, one very attractive approach for insoluble forms of phosphorus is the application of microorganisms. This group of bacteria can be found in the rhizosphere, at root surface and in association with roots.

Presenceofplantgrowth promotion rhizobacteria (PGPR) can improve extent or quality of plant growth directly or indirectly (Mehta et al. 2010). PGPR are directly involved in solubilization of minerals such as phosphorus; stimulation of seedlings root length increased uptake of nitrogen; production of siderophores that chelate iron and

\footnotetext{
Acknowledgements:

This study has been supported by the Serbian Ministry of Education, Science and Technological Development: Projects No. III46007 (New indigenous bacterial isolates Lysobacter and Pseudomonas as important sources of metabolites useful for biotechnology, plant growth stimulation and disease control: from isolates to inoculants) and BT31059 (Integrating biotechnology approach in breeding vegetable crops for sustainable agricultural systems).
} 
make it available to the plant root; synthesis of vitamins and phytohormones: indoleacetic acid (IAA), gibberellic acid, cytokinins, ethylene and efficient uptake of water (Meunchang et al. 2006, Mehta et al. 2010, Yasmin et al. 2012). Indirect promotion of plant growth occurs when PGPR lessen or prevent the deleterious effect of many pathogens, insects and nematodes through the production of antibiotics, lytic enzyme and hydrogen cyanide (Chaiahrn \& Lumyion 2008, Yasmin et al. 2012).

The phosphate-solubilizing microorganisms (PSM) are capable of hydrolysing organic and inorganic phosphorus from insoluble compounds, releasing phosphate available for plant uptake (Ahmad et al. 2008, Chaiahrn \& Lumyion 2008). Compared to fungi, phosphate solubilizing bacteria (PSB) are more effective in phosphate solubilization, which causes the wider potential uses of bacteria - they play a significant role in making phosphorus available to plants and enable the usage of less available sources of plant nutrients, such as rock phosphate. It is generally accepted that the major mechanism of mineral phosphate solubilization is the action of organic acid synthesized by soil microorganisms. Production of organic acid results in acidification of the microbial cell and its surroundings (Khan et al. 2009).

The aim of this study was to select endophytic bacteria from nodules of French bean grown in different intercropping systems with high ability of phosphate solubilization.

\section{Materials and Methods}

French bean was grown in agricultural field of Institute for Vegetable Crops, Smederevska Palanka (44⒉ $\left.1^{\prime} \mathrm{N}, 20^{\circ} 57^{\prime} \mathrm{E}\right)$, central Serbia. Endophytic bacteria were collected from the nodules of French bean grown in different systems: sole crop and intercropped with red beet and radish. Nodules formation was induced by indigenous rhizobia in all intercropping systems. Nodules were sterilized and bacteria were isolated on Yeast Manitol Agar (YMA) (Jošić et al. 2008). Pure cultures were obtained on YMA, King's B agar (KB) and Nutrient agar (NA) by restreaking several times (Djuric et al. 2011).

All bacterial isolates were screened on Pikovskaya (PVK) ( $\mathrm{gl}^{-1}$ : yeast extract, 0.5 ; agar, 15 ; glucose, 10 ; $\mathrm{Fe} \mathrm{SO}, 0.0001 ; \mathrm{MnSO}_{4}, 0.0001 ; \mathrm{MgSO}_{4} \times 7 \mathrm{H}_{2} \mathrm{O}$, $\left.0.1 ; \mathrm{KCl}, 0.2 ;\left(\mathrm{NH}_{4}\right)_{2} \mathrm{SO}_{4}, 0.5\right)$ growth medium supplemented with $5 \mathrm{gl}^{-1} \mathrm{TCP}$ for P-solubilization potential. Bacterial colonies surrounded by a halo (indicating removal of phosphate) on PVK medium were assumed to be capable for P-solubilization and selected for further assay on PVK and National Botanical Research Institutes Phosphate (NBRIP) $\left(\mathrm{gl}^{-1}\right.$ : glucose, 10; $\left(\mathrm{NH}_{4}\right)_{2} \mathrm{SO}_{4}, 0.1 ; \mathrm{KCl}, 0.2$; $\mathrm{MgSO}_{4} \times 7 \mathrm{H}_{2} \mathrm{O}, 0.25 ; \mathrm{MgCl}_{2} \times 6 \mathrm{H}_{2} \mathrm{O}, 5$; agar, 15) mediums (Kapri \& Tewari 2010). Insoluble TCP, $\mathrm{FePO}_{4}$ and $\mathrm{AlPO}_{4}$ in concentration of $4-6 \mathrm{gl}^{-1}$ were used as sources of phosphate in both mediums. The plates were prepared $24 \mathrm{~h}$ earlier and $10 \mu \mathrm{l}$ of $5 \times 10^{8} \mathrm{CFUml}^{-1}$ bacterial suspensions were injected in medium in triplicate. The plates were incubated

Table 1. Isolates from French bean nodules able to solubilize TCP and control strains used in this study

\begin{tabular}{ccc}
\hline Isolate & Locality & $\begin{array}{c}\text { French bean } \\
\text { intercropped with: }\end{array}$ \\
\hline MP2 & SP-S11 & radish \\
MP3 & SP-S11 & radish \\
MP7 & SP- K11 & radish \\
MP8 & SP- N1 & $/$ \\
MP9 & SP- N7 & red beet \\
MP17 & SP- K1 & $/$ \\
MP18 & SP- K11 & radish \\
MP19 & SP- N7 & red beet \\
& Control strains & soil \\
k-: Bacillus sp. strain B2 & Pančevo & maize rhizosphere \\
\hline k+: Pseudomonas sp. strain Q4 & Aranđelovac
\end{tabular}


at $26^{\circ} \mathrm{C}$ and halo zones were measured at 7 days of incubation.

Only isolates showing P-solubilization zone of 3 $\mathrm{mm}$ and more were selected for quantitative analysis (Table 1). Quantitative estimation of solubilized $\mathrm{P}$ was carried out in $25 \mathrm{ml}$ of Pikovskaya broth amended with $5 \mathrm{~g} / \mathrm{l} \mathrm{TCP}$. Before inoculation, the bacteria were cultured on Nutrient Broth at $26^{\circ} \mathrm{C}$ for $24 \mathrm{~h}$ and adjusted to $5 \times 10^{8} \mathrm{CFUml}^{-1}$. Medium was inoculated with $5 \times 10^{6} \mathrm{CFU}$ of each isolate, incubated at $27^{\circ} \mathrm{C}$ for 4 days at $150 \mathrm{rpm}$ and cultures were harvested by centrifugation at 5400 $\mathrm{rpm}$ for $10 \mathrm{~min}$. Total $\mathrm{P}$ amount in supernatants were estimated spectrophotometrically (Jelenić \& Džamić 1985).

Taxonomic characterization of selected isolate MP18 was performed on the basis of Gram staining, biochemical properties using API $20 \mathrm{NE}$ test (Biomerieaux, France) and genetic characterization of $16 \mathrm{~S}$ rRNA gene. Total DNA were isolated and $16 \mathrm{~S} \mathrm{rDNA}$ amplicon were yielded using $\mathrm{fD} 1 / \mathrm{rD} 1$ primer set (Weisburg et al. 1991, Jošić et al. 2012a). Sequence of obtained amplicon was compared to those in NCBI GenBank.

\section{Results and Discussion}

Total of $42.4 \%$ (67 out of 158 ) of endophytic bacteria isolated from French bean nodules belongs to indigenous rhizobia. All of 6 rhizobia that formed halo zones on PVK medium were concerned as poor TCP solubilizers, showing zones between 1 and $2 \mathrm{~mm}$. Other bacterial genera were represented by $57.6 \%$ of isolates (91) and only $8.79 \%$ among them showed ability to solubilize TCP in PVK medium. Two out of 8 selected isolates were isolated from nodules of French bean grown as a sole crop and two from nodules of French bean intercropped with red beet, as shown in Table 1. Four isolates originated from nodules of French bean near radish rhizosphere.

No growth was observed on NBRIP supplemented with $\mathrm{FePO}_{4}$ and $\mathrm{AlPO}_{4}$ and PVK supplemented with $\mathrm{AlPO}_{4}$. Control strains and 3 isolates grew on PVK supplemented with $\mathrm{FePO}_{4}$, but no halos were observed around the colonies. Since the direct measurement of phosphate solubilization in broth assay is likely to give more reliable results than a regular plate assay, the eight phosphate-solubilizing strains were further tested for their ability to solubilize TCP in PVK broth. The values of $\mathrm{P}$-solubilization zones, $\mathrm{pH}$ values and concentration of solubilized TCP in liquid PVK medium are shown in Table 2.

The selected isolates showed a wide range of TCP solubilization after four days: $14-182 \mathrm{gml}^{-1}$. MP18, isolated from nodules of French bean intercropped with radish, showed the highest phosphate

Table 2. Growth and phosphosolubilization ability on two solid (s) mediums and phosphate concentration in Pikovskaya liquid (lq) medium

\begin{tabular}{|c|c|c|c|c|c|}
\hline \multirow{3}{*}{ Isolate } & \multicolumn{5}{|c|}{ Medium } \\
\hline & $\operatorname{PVK}(s) \mathrm{FePO}_{4}^{\mathrm{a}, \mathrm{b}, \mathrm{c}}$ & $\begin{array}{c}\mathrm{PVK}(\mathrm{s}) \\
\mathrm{Ca}(\mathrm{PO}) \mathrm{b}\end{array}$ & $\begin{array}{l}\operatorname{NBRIP}(s) \\
\mathrm{Ca}(\mathrm{PO}) \mathrm{b}\end{array}$ & PVK & $\mathrm{Ca}_{3}\left(\mathrm{PO}_{4}\right)_{2}{ }^{\mathrm{b}}$ \\
\hline & $\begin{array}{c}\text { growth/ } \\
\text { P-solubilization }\end{array}$ & $\begin{array}{l}\text { zone of P-solubilization } \\
(\mathrm{mm})\end{array}$ & $\begin{array}{c}\text { zone of P- } \\
\text { solubilization } \\
(\mathrm{mm})\end{array}$ & $\mathrm{pH}$ & $\begin{array}{l}\text { conc. } \mathrm{P} \\
\left(\mu \mathrm{g} \mathrm{m} \mathrm{l}^{-1}\right)\end{array}$ \\
\hline MP2 & - & 5 & 3.5 & 5.20 & 51 \\
\hline MP3 & - & 6 & 4 & 5.57 & 14 \\
\hline MP7 & $+/-$ & 4.5 & 4 & 5.51 & 40 \\
\hline MP8 & $+/-$ & 5 & 3.5 & 5.22 & 28 \\
\hline MP9 & - & 6 & 3 & 5.01 & 81 \\
\hline MP17 & - & 7 & 3.5 & 5.08 & 26 \\
\hline MP18 & - & 6 & 5.5 & 4.91 & 182 \\
\hline MP19 & $+/-$ & 7 & 3.5 & 5.13 & 48 \\
\hline Q4 & $+/-$ & 8 & 3 & 4.53 & 246 \\
\hline B2 & $+/-$ & 4.5 & 4 & 5.40 & 29 \\
\hline
\end{tabular}

${ }^{*}$ concentration of insoluble phosphates added: ${ }^{\mathrm{a}}-6 \mathrm{gl}^{-1} ;{ }^{\mathrm{b}}-5 \mathrm{gl}^{-1} ;{ }^{\mathrm{c}}-4 \mathrm{gl}^{-1}$;

No growth: NBRIP supplemented with 4-6 $\mathrm{gl}^{-1} \mathrm{FePO}_{4}$ and $4-6 \mathrm{gl}^{-1} \mathrm{AlPO}_{4}$ and PVK supplemented with 4-6 gl ${ }^{-1}$ $\mathrm{AlPO}$ 
solubilizing efficiency among endophytic isolates $\left(182 \mu \mathrm{gml}^{-1}\right)$ and reached $73.98 \%$ efficiency of rhizospheric Pseudomonas sp. Q4 strain used as positive control. The minimal value of TCP solubilization in liquid PVK medium was observed for isolate MP3 from the same intercropping system, despite the same value of P- solubilization zone in solid PVK as the most efficient isolate. TCP solubilization for MP3 was lesser than for Bacillus sp. B2 strain, originated from contaminated soil, used as poor TCP solubilizer. The value of $81 \mu \mathrm{g}$ $\mathrm{ml}^{-1}$ was observed for MP9 isolated from nodules of French bean intercropped with red beet. Similar results are reported for different rhizospheric Pseudomonas strains. The solubilization of TCP is reported for different rhizospheric fluorescent pseudomonads belonging to $P$. monteilli, P. putida, $P$. plecoglossicida, P.fluoresens, P. fulva, P. monteilli and P. aeruginosa and soluble phosphate ranged from 29 to $105 \mathrm{\mu gml}^{-1}$ after 10 days of inoculation (BMC) (Naik et al. 2008). The value of $74.6 \mu \mathrm{gml}^{-1}$ soluble phosphate from inorganic phosphate is observed for P. fluorescens strain NJ-101 isolated from agricultural soil (Bano \& Mussarat 2004, Jošić et al. 2012a).

P-solubilization by MP18 was accompanied by a decrease in $\mathrm{pH}$ of the culture supernatants from 7.40 to 4.91 . Similarly, the $\mathrm{pH}$ value of 4.53 was observed after 4 days of cultivation for Pseudomonas sp. Q4 strain. Similar pH decrease (to 4.8) was observed for numerous taxonomically different rhizospheric fluorescent pseudomonads (BMC) (Naik et al. 2008). Although phosphate solubilization is not necessarily correlated with acidity, a basic principle is related to the production of organic acids and the releasing of protons ( $\mathrm{Lin}$ et al. 2006). It is correlated to our results for MP3 isolate where the lowest $\mathrm{pH}$ decreasing of medium (to 5.57) and the lowest TCP solubilization was recorded. The decrease in $\mathrm{pH}$ in relationship to release of soluble phosphates is also reported for free-living soil bacteria (Rajkumar \& Freitas 2008) and rhizobia (Sridevi et al. 2007). The phosphate solubilization depends not only to the quantity of organic acid secreted, but to the structural complexity and particle size of phosphates and other mechanisms (Nautiyal et al. 2000).

Characterization of selected isolate MP18, as the most efficient, was based on biochemical characteristics obtained by API 20NE test and $16 \mathrm{~S}$ rRNA gene sequence analysis. No fluorescent pigment production was observed on $\mathrm{KB}$ medium. Isolate MP18 was Gram-negative, motile, rod shaped, non-fluorescent, positive for cytochrome oxidase test and able to grow at $4^{\circ} \mathrm{C}$ and $42^{\circ} \mathrm{C}$. Comparison with similar sequences in NCBI GenBank showed 99\% similarity to several
Pseudomonas sp. and allowed to characterize it as Pseudomonas sp.

The bacteria belonging to Bacillus, Achrobacter, Aerobacter, Acinetobacter, Enterobacter, Mesorbizobium, Rhizobium, Klebsiella and Micrococcus, have been reported as phosphate solubilizers. However, strains belonging to Pseudomonas, especially fluorescent strains, are considered as efficient phosphate solubilizers (Villegas \& Fortin 2002). Among endophytic bacteria isolated from root nodules in various leguminous plants (alfalfa, clover, soybean, pigeon pea) are Agrobacterium, Bacillus, Pseudomonas, Burkholderia and Enterobacteria (Zakhia et al. 2006, Kan et al. 2007, Geetha et al. 2008, Li et al. 2008). The results from our study showed the most efficient phosphate solubilizing endophytic isolate MP18 belongs to Pseudomonas genera, according to phenotypic characters and $16 \mathrm{~S}$ rRNA gene sequence. The plant growth promoting traits of different endophytic (Stajković et al. 2011) and rhizospheric Pseudomonas spp. from Serbia is already reported and most of them are able to solubilize TCP (Djuric et al. 2011, Josic et al. 2012b). Besides being vital for photosynthesis, energy transfer and formation of sugars, $\mathrm{P}$ also promotes nitrogen fixation in legumes (Gaur 1990). Low levels of phosphorus reduce the population of legume-nodulating microorganisms and affect rhizobia-legume symbiosis (Moreira et al. 2010). Phosphate solubilization occurred by rhizobia isolated from Crotalaria sp. (Sridevi et al. 2007). Only rhizobia able to solubilize TCP in very low rate were observed in our study. The natural simultaneous presence of rhizobia and Pseudomonas sp. MP18 in French bean nodule may be explained by low P-solubilizing capacity of indigenous rhizobia and possibility of MP18 to improve availability of phosphorus for microsymbiont and host-plant.

Numerous studies confirmed beneficial effects of legumes in dual inoculation with rhizobia and PSB. Rudresh et al. (2005) reported the increase in nodulation and biological nitrogen fixation due to synergistic effect of rhizobia and PCB comparing to their individual application. Significant response of dual inoculation was observed in chickpea crop, increasing yield and leghemoglobin content in the nodular tissues (Barea et al. 2005). The dual inoculation of endophytic strains $P$. chlororaphis Zong1 and Mesorhizobium sp.SQ1 cause synergistic or addictive effect and improve not only phosphate solubilization, but also siderophores production, organic acid production, IAA production and in vitro antifungal activity, compared to single inoculation (Zhao et al. 2013). 


\section{Conclusions}

The selected endophytic Pseudomonas sp. MP18 isolate reached high phosphate solubilizing efficiency comparing to positive control. For the agricultural production it could be added to some microbial fertilizers and used especially on soils containing high amounts of insoluble TCP. Also, it could be suitable for organic production and other sustainable production systems. According to the obtained results, it will be further investigated for other PGP traits and synergistic effect with indigenous rhizobia.

\section{References}

Ahmad, F., Ahmad, I. \& Khan, M., S. (2008). Screening of freeliving rhizospheric bacteria for their multiple plant growth promoting activites. Microbial Research 163(9): 173-181. doi: 10.1016/j.micres.2006.04.001

Banerjee, S., Palit, R., Sengupta, C., \& Standing, D. (2010). Stress induced phosphate solubilisation by Arthrobacter sp. and Bacillus sp. isolated from tomato rhizosphere. Australian Jouranal of Crop Science 1(6): 378-383. Retrieved from http://www. cropj.com/

Bano, N., \& Musarrat, J. (2004). Characterization of a novel carbofuran degrading Pseudomonas sp. with collateral biocontrol and plant growth promoting potential. FEMS Microbiol. Lett. 231: 13-17. doi: 10.1016/s0378-1097(03)00894-2

Barea, J.- M.., Pozo, M. J., Azc'on, R., \& Azc'on-Aguilar, C. (2005). Microbial co-operation in the rhizosphere. Journal of Experimental Botany 417(56): 1761-1778. doi:10.1093/jxb/ eri197

Chaiahrn, M., \& Lumyong, S. (2008). Phosphate solubilization potential and stress tolerance of rhizobacteria from rice soil in Northern Thailand. World. J. Microbiol. Biotechnol. 2(5): 305314. doi: 10.1007/s11274-008-9892-2

Djuric, S., Pavic, A., Jarak, M., Pavlovic, S., Starovic, M., Pivic, R., $\&$ Josic, D. (2011). Selection of indigenous fluorescent pseudomonad isolates from maize rhisospheric soil in Vojvodina as possible PGPR. Romanian Biotechnological Letters, 16, 65806590. Retrieved from http://www.rombio.eu/

Gaur, A.C. (1990). Phosphorus solubilizing microorganisms as biofertilizer. New Delhi: Omega Scientific Publishers.

Geetha, R., Sing, F. J., Desai, A., \& Archana, G. (2008). Enhanced growth and nodulation of pigeon pea by co-inoculation of Bacillus strains with Rhizobium spp. Biores. Technol. 99: 45444550. doi:10.1016/j.biortech.2007.06.057

Jelenić, Đ., \& Džamić, R. (1985). Fitofiziologija, praktikum. Beograd: Poljoprivredni fakultet. (In Sr)

Jošić, D., Miličić, B., Mladenović-Drinić, S., \& Jarak, M. (2008). Genodiversity of dominant Rhizobium leguminosarum bv. trifolii isolated from 11 types of soil in Serbia. Genetika 40(2): 179-190. doi:10.2298/gensr0802179J

Josic, D., Delic, D., Rasulic, N., Stajkovic, O., Kuzmanovic, D., Stanojkovic, A., \& Pivic, R. (2012b). Indigenous Pseudomonads from Rhizosphere of Maize grown on Pseudogley Soil in Serbia. Bulgarian Journal of Agricultural Science 18(2): $197-$ 206. Retrieved from http://www.agrojournal.org/

Jošić, D., Pivić, R., Miladinović, M., Starović, M., Pavlović, S., Đurić, S., \& Jarak, M. (2012a). Antifungal activity and genetic diversity of selected Pseudomonas spp. from maize rhizosphere in Vojvodina. Genetika 44(2): 377-388. doi: 10.2298/gensr1202377J

Kan, F. L., Chen, Z. Y., Wang, E. T., Tian, C. F., Sui, X. H., \&
Chen, W. X. (2007). Characterization of symbiotic and endophytic bacteria isolated from root nodules of herbaceous legumes grown in Qinghai-Tibet Plateau and in other zones of China. Arch. Microbiol. 188: 103-115. doi: 10.1007/s00203007-0211-3

Kapri, A., \& Tewari, L. (2010). Phosphate solubilization potential and phosphatase activity of rhizospheric Trichoderma spp. Braz. J. Microbiol. 41(3): 787-795. Retrieved from http:// www.scielo.br/

Khan, A. A., Jilani, G., Akhtar, M. S., Naqvi, S. M. S., \& Rasheed, M. (2009). Phosphours solubilising bacteria: occurrence, mechanisms and their role in crop production. J. Agric. Biol. Sci. I(10): 48-58. Retrieved from http://www.uaar.edu.pk/

Li, J. H., Wang, E. T., Chen, W. F., \& Chen, W. X. (2008). Genetic diversity and potential for promotion of plant growth detected in nodule endophytic bacteria of soybean grown in Heilongjiang province of China. Soil Biol. Biochem. 40: 238246.

doi:10.1016/j.soilbio.2007.08.014

Lin, T. F., Huang, H., Shen, F. T., \& Young, C. C. (2006). The protons of gluconic acid are the major factor responsible for the dissolution of tricalcium phosphate by Burkholderia cepacia CC-A174. Bioresource Technology 97: 957-960. doi:10.1016/j. biortech.2005.02.017

Madigan, M. T., \& Martinko, J. M. (2006). Brock biology of microorganisms $\left(11^{\text {th }}\right.$ ed.). New York: Pearson Prentice Hall.

Mehta, P., Chauhan, A., Mahajan, R., Mahajan, P. K., \& Shirkot, C. K. (2010). Strain of Bacillus circulans isolated from apple rhizosphere showing plant growth promoting potential. $\mathrm{Cu}$ rrent Science 98(4): 538-543. Retrieved from http://www. currentscience.ac.in/

Meunchang, S., Thongra-ar, P., Saonoh, S., Kaewsuralikhit, S., \& Ando, S. (2006). Development of Rhizobacteria as a biofertilizer for rice production. In: International Workshop on Sustained Management of the Soil-Rhizosphere System for Efficient Crop Production and Fertilizer Use 1(7): 1-7. Retrieved from http://www.agnet.org/htmlarea_file/ activities/20110719102200/12.pdf

Moreira, F. M. S., Carvalho, T. S., \& Siqueira, J. O. (2010). Effect of fertilizers, lime, and inoculation with rhizobia and mycorrhizal fungi on the growth of four leguminous tree species in a low-fertility soil. Biology and Fertility of Soils 46: 771-779. doi: 10.1007/s00374-010-0477-5

Naik, P. R., Raman, G., Narayanan, K. B., \& Sakthivel, N. (2008). Assessment of genetic and functional diversity of phosphate solubilizing fluorescent pseudomonads isolated from rhizospheric soil. BMCMicrobiology 8: 230. doi:10.1186/1471-2180$8-230$

Nautiyal, C. S., Bhadauria, S., Kumar, P., Lal, H., Mondal, R., \& Verma, D. (2000). Stress induced phosphate solubilization in bacteria isolated from alkaline soils. FEMS Microbiol. Lett. 182(2): 291-296. doi: 10.1111/j.1574-6968.2000.tb08910.x

Rajkumar, M., \& Freitas, H. (2008). Effects of inoculation of plant-growth promoting bacteria on Ni uptake by Indian mustard. Bioresource Technology 99: 3491-3498.

doi: 10.1016/j.biortech.2007.07.046

Rudresh, D. L., Shivaprakash, M. K., \& Prasad, R. D. (2005). Effect of combined application of Rhizobium, phosphate solubilizing bacterium and Trichoderma spp. on growth, nutrient uptake and yield of chickpea (Cicer aritenium L.). Applied Soil Ecology 28(2): 139-146.

doi: 10.1016/j.apsoil.2004.07.005

Sridevi, M., Mallaiah, K. V., \& Yadav, N. C. S. (2007). Phosphate solubilization by Rhizobium isolates from Crotalaria species. Journal of Plant Sciences 2(6): 635-639. Retrieved from http:// www.docsdrive.com/pdfs/academicjournals/

Stajković, O., Delić, D., Jošić, D., Kuzmanović, Đ., Rasulić, N., \& Knežević-Vukčević, J. (2011). Improvement of common bean growth by co-inoculation with Rhizobium and plant growth- 
promoting bacteria. Romanian Biotechnological Letters 16: 5919-5926. Retrieved from http://www.rombio.eu/

Villegas, J., \& Fortin, J. A. (2002). Phosphorus solubilization and $\mathrm{pH}$ changes as a result of the interactions between soil bacteria and arbuscular mycorrhizal fungi on a medium containing $\mathrm{NO}_{3}$ - as nitrogen source. Can. J. Bot. 80(5): 571-576. doi: 10.1139/b02-038

Weisburg, W. G., Barns, S. M., Pelletier, D. A., \& Lane, D. J. (1991). 16S ribosomal DNA aplification for phylogenetic study. Journal of Bacteriology 173(2): 697-703. Retrieved from http://jb.asm.org/

Yasmin, H., Bano, A., Samiullah, Naz, R., Farooq, U., Nosheen, A., \& Fahad, S. (2012). Growth promotion by P-solubilzing, siderophore and becteriocin producing rhizobacteria in $Z e a$ mays L. Journal of Medicinal Plants Research 1(4) 553-559. doi: $10.5897 /$ jmpr11.625

Zakhia, F., Jeder, H., Willems, A., Gillis, M., Dreyfus, B., \& De Lajudie, P. (2006). Diverse bacteria associated with root nodules of spontaneous legumes in Tunisia and first report for nif $H$ like gene within the genera Microbacterium and Starkeya. Microbial. Ecol. 51: 375-393. doi: 10.1007/s00248-006-9025-0

Zhao, L. F., Xu, Y. J., Ma, Z. Q., Deng, Z. S., Shan, C. J., \& Wei, G. H. (2013). Colonization and plant growth promoting characterization of endophytic Pseudomonas chlororaphis strain Zong1 isolated from Sophora alopecuroides root nodules. Brazilian Journal of Microbiology 44(2): 623-631. doi: 10.1590/ S1517-83822013000200043

\title{
Solubilizacija neorganskih fosfata endofitim Pseudomonas sp. iz nodula boranije
}

\author{
Zoran Dinić • Milan Ugrinović • Predrag Bosnić • Mira Mijatović • \\ Jasmina Zdravković • Miroslav Miladinović • Dragana Jošić
}

Sažetak: Fosfor (P) je jedan od esencijalnih makronutrijenata potrebnih za rast biljaka. Fosfosolubilizirajuće bakterije (PCB) spadaju u grupu heterotrofnih bakterija sposobnih da solubilizuju fosfor iz nerastvornih organskih i neorganskih jedinjenja, oslobađajući fosfor koji je dostupan biljkama. U ovom radu su ispitivane endofite bakterije izolovane iz nodula boranije gajene u različitim sistemima interkropinga. Samo 14 od 158 endofitih izolata je solubilizovalo trikalcijum fosfate (TCP). Nijedan izolat nije solubilizovao $\mathrm{FePO}_{4}$ i $\mathrm{AlPO}_{4}$. Osam izolata je formiralo zone solubilizacije šire od 3 $\mathrm{mm}$ i selektovano je za dalji rad. TCP solubilizacija je kvantifikovana u tečnom Pikovskaya medijumu i iznosila je 14-182 $\mu \mathrm{gml}^{-1}$ rastvorenog fosfora. TCP solubilizacija je praćena zakišeljavanjem medijuma, a izmereno je opadanje $\mathrm{pH}$ sa 7,4 na 5,57 i 4,91 kod izolata sa najmanjim i najvećim solubilizacionim potencijalom. Selektovan je najefikasniji izolat MP18 i identifikovan kao Pseudomonas sp. prema izvršenoj analizi sekvence $16 \mathrm{~S}$ rRNK gena.

Ključne reči: endofite bakterije, fosfosolubilizirajuće bakterije, noduli boranije, Pseudomonas, zemljišni pH 